\title{
SAFE COUNTRY OF ORIGIN LIST AT THE EU LEVEL: THE BARGAINING PROCESS AND THE IMPLICATIONS
}

Anca Gurzu

Carleton University

\begin{abstract}
Critics have often highlighted that the 1999 Tampere decision to establish a common European Union (EU) asylum system has been too focused on security and not enough on human rights, leading to increased denial of protection for asylum seekers. This paper focuses on a controversial asylum policy, which is part of this debate: the safe country of origin (SCO) policy. This policy revolves around having a list of countries deemed "safe," which ensures asylum seekers from these countries are fast tracked through the system and likely denied asylum in the end, based on a general assumption that the application is unfounded. Human rights groups have argued the SCO policy violates the Geneva Convention. Widely used at the national level, officials proposed the creation of a supranational SCO list in the early 2000s. However, disagreements among Member States over what countries to deem "safe," as well as the need to place the European Parliament in a co-decision (as opposed to consultative) position for the creation of the EU SCO list have led to an impasse. This paper employs two major European integration theories, neofunctionalism and liberal intergovernmentalism, to explain the bargaining dynamics between Member States and their failure to agree on what "safe" means. Factors such as different national migratory pressures, varied procedural understandings and applications of the SCO policy, a limited successful harmonization in related asylum policies, along with a reluctance to have the European Parliament in a co-decision position all contributed to the non-adoption of a supranational SCO list.
\end{abstract}




\section{Introduction}

European Union (EU) Member States set themselves a new goal at the European Council Summit in Tampere in 1999: to establish a common EU policy on immigration and asylum. The 2004 Hague Programme brought the initiative into a second phase, calling for deeper procedural harmonization through binding instruments with an adoption deadline of 2010 (Lindstrom 2005, 600 ). It even speculated on the idea of joint processing of asylum applications within the EU. The Stockholm Programme (2010-2014) envisions a deepening of this common roadmap, calling for a functional Common European Asylum System by 2012.

Despite these initiatives, the road has not been an easy one. Implementation of common EU asylum policies is a challenging endeavour. Sandra Lavenex $(2001,852)$ writes of two paradoxes in the Europeanization of refugee policies: (1) the tension between state sovereignty and supranational governance, and (2) the tension between internal security and human rights issues. Channe Lindstrom $(2005,588)$ points out that current policy methods meant to harmonize Member States' asylum policies establish in fact "legitimacy for the denial of protection [...] by shifting responsibility away from the European territorial core.”

Since the Tampere summit, European Union Member States have had to legally abide to key EU directives and regulations that set the ground rules for several asylum-related policies. ${ }^{1}$ While these have strengthened some aspects of EU law, Bruce Leimsidor $(2009,9)$ argues the positive results have been limited. More striking is a lack of an effective enforcement mechanism and the highly politicized asylum adjudication process within the EU, which lead to inconsistencies. Scholars have generally argued that attempts to harmonize immigration and refugee policies over the years have in fact allowed Member States to pursue their domestic objectives by other means, such as externalizing "worst practices” (Lindstrom 2005, 592) and perpetuating harmonization with the lowest common denominator (Lavenex 2001, 865). Overall, while the Tampere conclusions left room for optimism by seeming to uphold the principle of asylum under the Geneva Convention, the eventual focus on security concerns "took away with one hand what it seemed to give with the other" (Leimsidor 2009, 6).

Building on this last point, this paper will delve into a less known, but controversial, asylum policy tool, which represents an important element of the proposed harmonized EU asylum system: the safe country of origin policy (SCO). According to the United Nations High Commissioner for Refugees, the term is used in reference to countries determined to be nonrefugee producing countries (UNHCR 1991). In a nutshell, this policy implies having a list-either formal or informal - of countries deemed "safe" based on various criteria often related to the democratic practices, human rights protection, and judicial independence of that country. Already applied at the national level in several EU Member States, this policy ensures that asylum seekers from "safe" countries are fast tracked through the system and returned to their home country based on a general assumption that the asylum claim is unfounded. Refugee and human rights groups have been highly critical of the SCO policy, arguing it violates basic rights outlined in the Geneva Convention.

1. These include the 2001 Directive laying down the minimum standards for giving temporary protection in the event of mass influx of displaced persons; the 2003 Directive laying down the minimum standards for the reception of asylum seekers, followed by the so-called Dublin II Regulations of the same year, which aim to establish which Member State is responsible for deciding an asylum claim (usually the first EU country the asylum-seeker initially arrives in); the 2003 Directive on right to family reunification; the 2004 Directive laying down the standards for the qualification of third country nationals or stateless persons as refugees; and the 2005 Directive outlining the minimum standards on procedures for granting and withdrawing refugee status, which also covers the SCO principle. 
As part of the ongoing process to reach a common integrated asylum system among Member States, the idea of having a list of "safe" countries at the supranational level that would apply to all EU Member States has already surfaced several times. However, although the SCO policy is not new to representatives from Member States, it has proven exceptionally difficult for them to find consensus on what "safe" means and what countries should be on the pan-EU list. The lack of consensus among EU Member States and the decision by the European Court of Justice (to be discussed later in this paper) have put the debate about a common SCO list on hold. But, while progress on the EU list has stalled, this may only be temporary. As Member States gradually start implementing more and more common asylum practices, and as supranational bodies like the European Asylum Support Office become fully operational, reviving the debate around the EUlevel SCO list may be only a matter of time. This is why the study of the SCO refugee policy is an important endeavour. It could contribute to the still-evolving EU asylum literature, which has largely only glanced over this specific concept. ${ }^{2}$

The purpose of this paper is to theorize and explain the process of creating a common EU SCO list, as well as to assess the political implications behind such a list. The two theories that will aid in this process are neofunctionalism and liberal intergovernmentalism. They are often used to explain European integration, but are rarely applied in specific reference to asylum policy. These theories will be used in a complementary way to explain the policy making process behind the supranational SCO list, highlighting the dynamics between Member States and EU institutions throughout. Implicitly, the analysis will also identify the combination of factors that led to the current stalemate and how a change in these factors could reopen the debate.

The argument of this paper is that Member States could not agree on the pan-EU SCO list because they arrived at the bargaining table with different national migratory pressures coupled with varied procedural understandings and applications of the SCO policy. Furthermore, the limited success in harmonization of related asylum policies and a reluctance to have the European Parliament in a co-decision position both also contributed to the non-adoption of a supranational SCO list. This paper will explore the bargaining process between Member States regarding the definition of "safe" by appealing to the lowest common denominator argument. Because of the factors highlighted above, it may be easier to eventually reach a consensus and settle everyone's preferences by creating a longer-rather than a shorter-list of safe countries of origin.

This paper is composed of four main sections. The first section will briefly outline how neofunctionalism and liberal intergovernmentalism explain European integration broadly, and immigration and asylum integration, more specifically. The second section will track the evolution of the SCO list at the EU level. In order to understand the complexities behind setting up the EU SCO list, the third section will highlight the different use of this policy at the national level of Member States. The last section will then employ the two theories to sustain the main arguments of this paper, while the concluding remarks will predict the way forward.

\section{Theorizing European Integration}

Despite their popularity in attempting to explain integration as a general phenomenon, there have been only few attempts to apply neofunctionalism and liberal intergovernmentalism to explain the drive towards a common immigration and asylum system. Moreover, this is the first attempt to apply the theories to this specific asylum policy tool.

2. It is also important to underline that this paper will only focus on the principle of safe countries of origin, not on the related notion of safe third countries, which refers to a "safe" country that the asylum seeker passed though and where he or she could have asked for asylum. 


\section{Neofunctionalism}

The neofunctionalist concept of spillover offers a good starting point in explaining integration. According to this theory, if the project of a single market-including the free movement of people-is to be completed, certain additional policies have to be implemented in such areas as visas, asylum, immigration, and police coordination (Niemann and Schmitter 2009, 57). This means that integration of one sector at the regional or supranational level can only be fully successful if it is combined with the integration of another sector, since problems arising from the functional integration of the former can only be solved by integrating the latter as well (Niemann and Schmitter 2009, 49). Neofunctionalists place rational, self-interested actors at the centre of the integration process. Unlike realists, neofunctionalists do not see states as the sole relevant actors but argue that players are multiple, diverse, and changing and that they are not restricted only to the domestic realm. The actors' interests are not constant but are likely to change during the integration process, as they learn the benefits of regional policies and gain experience in cooperative decision making (Niemann and Schmitter 2009, 48). Moreover, as opposed to the lowest common denominator bargaining prescribed through intergovernmentalism, neofunctionalists see supranational institutions as facilitating a bargaining process that upgrades common interests. Member States agree on a common standard so as not to jeopardize those areas where consensus already prevails (Niemann and Schmitter 2009, 50). Bodies like the European Commission play the role of "an institutionalized mediator" that with time gains an increasingly important role in the integration process (Niemann and Schmitter 2009, 50).

In the case of immigration and asylum, neofunctionalists would argue that there is a strong functional interdependence between external border control and visa policy, for example. For states to waive their powers of internal control, they need to be provided with an equivalent protection by shifting control to the most external borders of the Community, by creating a common visa policy and regulating admission into the EU. The Schengen Agreement, as well as the several carrot-and-stick approaches the EU has been pursuing with neighbouring non-EU states in the areas of migration stand as concrete examples. There is also a strong functional pressure and spillover towards the creation of a common asylum system, so that the restrictive measures of one state are not undermined by the liberal measures of another (Niemann and Schmitter 2009, 57). The Dublin Regulations clearly exemplify this rationale, and-as this paper will later show-the spillover concept is also relevant in explaining the move towards a common EU SCO policy.

\section{Liberal Intergovernmentalism}

While the neofunctionalists' spillover effect provides a reasonable perspective as to why EU Member States are moving in the direction of a common immigration and asylum system, liberal intergovernmentalism adds to this understanding by focusing on the decision making process to explain specific policy initiatives. Like neofunctionalists, liberal intergovernmentalists see the main actors as rational. This means that agreement to cooperate stems from a collective outcome of interdependent rational state choices and intergovernmental negotiations (Moravcsik and Schimmelfennig 2009, 68). Rationally, a state will have an incentive to cooperate with other states when cooperation can eliminate negative externalities or create positive ones more efficiently than unilateral action could (Kraft-Kasack and Shisheva 2008, 4). However, unlike neofunctionalists, liberal intergovernmentalists see states as the only actors involved in the European integration process. Accordingly, Member States are seen as actors continuing to enjoy decision making power and political legitimacy (Moravcsik and Schimmelfennig 2009, 68). States have national 
preferences, which are issue specific and which may vary within each state and throughout time. In other words, the national preferences of different states will often conflict. Hence, the outcome of intergovernmental negotiations depends on the relative bargaining power of the actors.

Liberal intergovernmentalists see the EU as developing incrementally, with Member States likely to retain control over many major fiscal activities. Yet, while Member States pursue their national interests through hard bargaining, they are also likely to respond to supranational policy making in salient cases (Moravcsik and Schimmelfennig 2009, 84). In the case of asylum, since domestic social actors largely shape the national preferences of governments, liberal intergovernmentalism would predict that states put forward restrictionist refugee policies to reflect the interests of a mobilized set of actors in countries where ethnic and human rights groups are weak (Kraft-Kasack and Shisheva 2008, 6).

\section{A Supranational SCO List?}

EU interior ministers made the push towards a common EU list of safe countries of origin in October 2003, three years after the meeting in Tampere (EurActiv 2003). Since then, EU Member States' representatives continued meeting in order to reach an agreement on this pan-EU asylum policy. The call for the creation of an EU safe country of origin list was included in a draft directive in April 2004 (Council of the European Union 2004a). According to the annex following the draft directive, "[a] country is considered as a safe country of origin where, on the basis of the legal situation, the application of the law within a democratic system and the general political circumstances, it can be shown that there is generally and consistently no persecution" (Council of the European Union 2004a). In making this judgment, officials must assess how laws and regulations are applied in that country and whether the stipulations of various international documents are upheld, such as the Geneva Convention or the International Covenant for Civil and Political Rights (Council of the European Union 2004a).

In September 2004, media reports made the proposed list public. The countries on it were Benin, Botswana, Cape Verde, Chile, Costa Rica, Ghana, Mali, Mauritius, Senegal, and Uruguay. Reports indicated that if all Members would accept this list, states would be able to add countries to their national lists but would not be able to remove any from the EU list (Travis 2004). These ten countries were chosen based on a preliminary assessment of Member States' experiences in using the SCO principle at the national level, the number of asylum applications lodged in the Member States by nationals of those countries, and by assessing provisions laid down in several EU and international human rights conventions (Council of the European Union 2004).

Internal documents obtained by the non-profit organization Statewatch in September 2004, which will be addressed again later in this paper, indicated that Member States were highly divided over the proposed list. A Council note from November 9 2004, concluded that Member States were not able to reach agreement on the safe country of origin list (Council of the European Union 2004b). In September 2005, while generally supportive of the draft Directive calling for the harmonization of asylum policies across the EU, the European Parliament voted, nonetheless, against the idea of an EU SCO list (BBC 2005). Its opinion was non-binding, however.

On December 1 2005, EU Member States adopted the Council Directive setting the minimum standards on procedures for granting and refusing refugee status at the EU level. While the Asylum Procedures Directive was not joined by a specific list of safe countries of origin, it did however make the use of the SCO policy binding on Member States (Council Directive 2005). The expectation was to draft the SCO list after the adoption of the Directive. However, media reports from May 2006 revealed that Member States' officials could still not reach an agreement over 
which countries should feature on this supranational list. A draft proposal by then EU Justice Commissioner Franco Frattini included the exact seven African countries as two years before but excluded the Latin American countries (Kubosova and Küchler 2006). Just a month later, Frattini informed EU interior ministers that he was preparing a longer list of "safe" countries that would also include countries from Central America, Asia, and the West Balkans (Kubosova 2006). His move came reportedly in response to critiques arguing against the list's exclusivity.

Developments were brought to a halt on May 6 2008, when the European Court of Justice ruled that the Council of the European Union had exceeded its powers granted by the Treaty when making the future adoption of common lists of safe countries subject to mere non-binding consultations with the European Parliament. The Court also ruled that the adoption of any future lists would have to result from a co-decision procedure with the Parliament (European Court of Justice 2008).

The 2005 Directive is currently under recast. The European Commission presented the first proposal amending the Asylum Procedures Directive in October 2009. It makes modifications to the SCO principle, calling-more importantly-for the deletion of a common supranational SCO list (European Commission 2009). The proposal calls instead for the consolidation of the common criteria used for national designations of countries as safe, with the hopes of achieving more consistent applications of the SCO policy throughout Member States (European Commission 2009). The European Parliament adopted a first reading position on this proposal on April 62011 and the Commission presented a modified proposal on June 1 2011, which includes the same amendments related to the deletion of the common SCO list. At the time this article was being written, the proposal for the recast directive of 2005 was being negotiated in the Council and the European Parliament with an expected adoption date in 2012. Simultaneously, the two EU institutions were also negotiating the recast of another asylum-related directive from 2003, with the final goal of bringing Member States closer to the Common European Asylum System. Due to various political sensitivities surrounding these two pieces of EU legislation, it is unclear whether the deadline will be met.

At first glance, it appears that the proposed amendments for the 2005 Directive-and the 2008 European Court of Justice ruling-have created a setback in the creation of a common EU SCO list. However, a deeper analysis will show this may be only a temporary setback. For example, the Commission's amendment proposals from 2009 and 2010 also mention that the creation of a common SCO list, and the elimination of the national lists, could be considered viable once the European Asylum Support Office has the resources to sustain this new policy (European Commission 2011). Hence, while the common EU list does not exist yet, official discourses do not rule out the possibility of its development in the future.

\section{SCO Policies at the National Level}

In order to fully understand why Member States had such difficulty agreeing on what "safe" means, it is important to grasp the complex and various uses of the SCO policy at the Member State level, as well as some of the criticisms directed towards it. The first country to adopt the SCO policy as part of the asylum law was Switzerland in 1990 (Costello 2005, 50). Cathryn Costello notes that the concept then spread not through formal harmonization, but through administrative policy sharing interactions (2005, 50). After Switzerland, other countries followed suit: Austria, Finland, and Luxembourg in 1991, Germany in 1992, Portugal in 1993, Denmark in 
1994, the Netherlands in 1995, and the United Kingdom (UK) and France in 1996 (Costello 2005, 50). It is also interesting to note that Belgium had first introduced the policy in 1991, but in 1993 a domestic court ended the practice by declaring it a violation to the right of equality (Costello 2005, 51).

The European Commission adopted in 2010 a report evaluating the application of the 2005 Asylum Procedures Directive, which, among others, also assesses how Member States had been applying the SCO provisions at the national level. By 2010, the SCO notion did not exist in Belgium, Italy, Sweden, and Poland as it refers to national designations; however, these countries had transposed the SCO notion as it related to the common supranational list (European Commission 2010). Besides the fact that not all Member States employed this policy, the Commission found "wide divergences" among those Member States that do use the procedure (European Commission 2010). For example, in Cyprus, Estonia, Hungary, and Greece the SCO notion is applicable only to a part of a country, while the UK can choose to designate a country or part of a country as safe for a specified group of people (European Commission 2010). The report also notes that while national laws generally provide for a list of SCO, they have actually been adopted only in Austria, Germany, France, Romania, Slovakia, Luxembourg, and the UK. Even for these countries that use the lists, the contents vary; Member States chose different countries to consider as safe and the numbers also differ significantly. Furthermore, in Estonia, the Czech Republic, Finland, the Netherlands, and Portugal, no lists are foreseen and the notion may be applied on a case by case basis (European Commission 2010).

It is thus clear that when debating the creation of a common EU SCO list, Member States' officials may share a similar understanding of the concept as it relates to its purpose and outcome, but they vary considerably in their procedural understandings. It may be also fair to say that the differences observed across EU Member States regarding the use of the SCO policy tool reflect broader differences in migration pressures over the years coupled with overall different levels of restrictive versus more liberal refugee systems.

\section{Humanitarian Considerations}

Criticism over the use of the SCO principle has been plenty, but some scholars have defended the concept. For example, Kay Hailbronner wrote in 1993 that "the basic idea is to single out at an early stage those applicants who have nothing to fear in their home country and who can therefore be presumed to have abused the asylum procedure to circumvent immigration laws” $(1993,32)$. While this argument is in line with the official justifications often heard at the national level, there are not only clear concerns over the national use of the SCO principle, but also stronger concerns at the supranational level.

Sharon Oakley $(2007,5)$ points out that the case for speedier decision making-a key characteristic of the SCO concept-needs to be balanced against the requirement of Member States to fulfill their obligations under international human rights and refugee law. But, in order to achieve a faster processing system, procedural safeguards are reduced. This means that applicants from a safe country of origin do not have access to the same examination procedures as applicants falling under the regular asylum system. Furthermore, this implies that a fast tracked asylum seeker may not have access to free legal advice, may not have her or his case heard in a personal interview, and may not have the right to appeal (Oakley 2007, 5). Some scholars have even pointed towards a deterioration of the procedural use of the SCO principle over the years (Costello 2005, 52). For example, since 1996, France does not give asylum seekers from countries 
designated as safe the right to suspensive appeal, ${ }^{3}$ while the UK introduced a scheme to "super fast track” applicants from certain countries, with a time limit of two days (52). All in all, refugee and human rights groups have warned that states might be compromising their international obligations when they prioritize speed over fairness (Oakley 2007, 5).

The UNHCR states that it does not oppose the SCO concept "as long as it is used as a procedural tool to prioritize and/or accelerate examination of an application in carefully circumscribed situations” (UNHCR 2010, 65). However, it further qualifies this statement by highlighting that it is critical that each examination be examined fully on its merits; that the applicant has "an effective opportunity" to rebut the presumption of safety of the country of origin in his or her circumstances; that the burden of proof on the applicant is not increased; and that applicants have the right to appeal a negative decision (66).

In a March 2010 report, prior to the Commission report mentioned above, the UNHCR found "significant divergence" in the criteria used to designate a country as safe, ${ }^{4}$ specifically pointing to a lack of regulation, transparency, and accountability in the process some countries use (UNHCR 2010, 69). This included an absence of clear provisions for reviewing the safety of countries over time. The UNHCR also recommended that applicants "should not be afforded a lower standard of reception conditions and/or detained solely because they are nationals of a country designated as a safe country of origin” (70).

\section{The Future of the EU SCO List}

As mentioned above, the European Court of Justice (ECJ) decided in 2008 to annul the provision calling for the creation of a supranational SCO list, adding that any future lists would have to be drafted in co-decision with the European Parliament. The debate on this topic has since been muted, and some observers argue it could be because Member States may not be ready to see Parliament play such an important role, especially in the field of asylum, tightly connected to the notion of sovereignty. The second part of this section will theorize whether bringing in an equal supranational player really causes an insurmountable deadlock for the SCO list or whether the debate might be reopened.

\section{Bargaining for an EU SCO List}

The fact that Member States (and the European Commission) were unsuccessful a few years ago in agreeing which specific countries to include in the supranational SCO list is not a secret. What is interesting, however, is to assess the level of this disagreement. Documents obtained by Statewatch highlight the difficulty Member States had in reaching consensus over what "safe" really means. As mentioned above, Member States were trying to assess safety in ten proposed countries, seven from Africa and three from Latin America.

An analysis shows, for example, that Sweden and Finland opposed including four African countries, while Germany opposed including three. On the other side of the spectrum, it is

3. This means that an asylum seeker whose claim was deemed unfounded, may be deported while the appeal process is ongoing.

4. The exact focus was on how Member States designate safe third countries as safe countries of origin. This is slightly different than just employing the SCO list (as it involves taking countries previously designated as safe to claim asylum in and designating them as safe countries of origin). This paper will not insist on this specific differentiation, and will instead just focus on the general findings of the report, since they highlight the SCO principle in broad terms. 
important to note that the Czech Republic, France, Ireland, Hungary, Portugal, and Slovakia deemed all these seven countries to be safe. The rest of the Member States fell somewhere in the middle; many of them even abstained from judging the safety of a certain country (Statewatch 2004). While Denmark, Germany, Poland, and the UK fully abstained in judging the safety of the Latin American countries, all the votes that did exist deemed these three countries as safe (Statewatch 2004). It is also interesting to point out that many of the new Member States from Central and Eastern Europe, which are largely countries of emigration not immigration, had a higher rate of voting the proposed countries as "safe," compared to older Member States. This dynamic would be worthy of further investigation, however it is beyond the scope of this paper.

As leaked Council documents show, when they provided their votes, Member States' officials also had the opportunity to include comments that could justify their decision in nominating a country as safe or not. It is interesting to observe that even in cases where a country was deemed "safe," many Member States also included their concerns about the country's various practices as they relate to human rights, the death penalty, and other issues. In short, while reservations remained, some Member States nevertheless chose to nominate a country as safe. In other situations, the same reservations led other Member States to declare a country not "safe" (Statewatch 2004).

Liberal intergovernmentalism offers interesting insights when explaining the above dynamics. According to this theory, Member States arrive at the negotiating table with different national preferences, which may often conflict. The theory further claims that the outcome of a negotiation is based on the bargaining power of the states involved. In the case of the SCO principle, various groups have claimed that countries like the UK, France, Germany, Italy, and Spain are putting pressure on the smaller Member States to agree to the measure (Statewatch 2004).

Since Member States have different procedural understandings of the SCO concept-while some states do not employ it at all-and since the above analysis shows how varied views can be regarding what is "safe," it may be easier for Member States to eventually compromise on a longer, rather than a shorter, list to meet everyone's preferences. Furthermore, in order to reach the needed compromise, liberal intergovernmentalism would predict supranational SCO practices and lists to resemble those of the states who are already "well-versed" in using the refugee policy tool. This would be against the neofunctionalists' claim that sees supranational institutions as upgrading common interests during negotiations.

There are several developments that support the liberal intergovernmentalist assumption. First, not all Member States use the SCO policy or list at the national level. By adopting the SCO list at the EU level, Costello (2005) notes, Member States "are required to dilute their standards of protection by a measure of EC law" (65). The EU SCO list would represent the lowest common denominator, reflecting a vertical shift of the exclusionary procedural practices of Member States (Costello 2005, 37). A related and broader example of this liberal intergovernmentalist phenomenon is Germany's decision to participate in common asylum measures in the early 1990s. Fears over a potential influx of asylum seekers after the entry into force of the Schengen Agreement led the German government to look for European solutions. But in order to do that, Germany had to reform its fairly generous asylum system into a more restricted one (Kraft-Kasack and Shisheva 2008, 12). In case of the SCO list, it is easy to see how its development would create a similar outcome for those countries that are not as familiar with this restrictive refugee policy tool-but which they would have to employ.

To further this point, it is also liberal intergovernmentalism that explains why Member States that do not use SCO lists, or do not even use the principle per se, chose nevertheless to join negotiations that could have led towards the creation of such a supranational list. For example, the 
documents revealed by Statewatch showed that Sweden and Poland, which do not use the SCO policy for national designations, participated in the negotiations. According to the liberal intergovernmentalist theory, states choose to cooperate with other countries when the outcomes are more efficient than those obtained through unilateral action. Considering that asylum policies will continue down the path of communitarization, it may be more "economical" for these states to pursue the supranational solution.

As regards the specific "safe" countries on the list, it is important to remember that Member States decided to drop three Latin American countries from the list because of low numbers of asylum requests coming from nationals of those countries. ${ }^{5}$ However, the second time the list was proposed, reports indicated that including only countries from Africa on the SCO list is not enough. The 2004 Council note explaining that the decision on the SCO list would be postponed also included an important line regarding this idea: "If agreement was reached on a more limited list, there is a risk that such a list would not be useful in practice" (Council of the European Union 2004). This statement holds considerable weight and it truly reflects the national preferences of those countries that often utilize the SCO principle at the national level. It is hard to believe, for example, that countries like the UK, whose list of SCO is generally long and fluid, would easily accept a common EU list that is much shorter and "safe" countries that the UK does not see as problematic. This only reinforces the point that a longer list, rather than a shorter one, would represent a satisfactory outcome of the bargaining process, according to the liberal intergovernmentalist perspective. Member States could easily justify having more countries on the SCO list by presenting it as an aggregate of everyone's preferences and of domestic migration conditions. Adding more countries to the supranational SCO list is not in any way detrimental to the Member States themselves, but only to asylum seekers arriving from the "safe" countries. These would probably enjoy fewer rights and their asylum claims would be more scrutinized. But, Member States could claim to be operating under a more communitarized system as a result of a bargaining process that met everyone's expectations. While it is fair to point to examples from previous years and underline that officials could not agree on what "safe" means and what countries should feature on the list, one could argue that future asylum policy harmonization could bring different procedural understandings closer together in time and push once more for the list's creation.

\section{Reviving the Debate?}

Despite the above analysis of the dynamics that could shape the creation of a common EU SCO list, the reality is that progress has stalled. The 2008 ECJ decision asking for the European Parliament to be included as a co-decider in the approval of any future list of "safe countries" seems to have complicated matters. Moreover, the 2005 Directive that initially called for the creation of the common SCO list is currently under recast; but, while Member States may have difficulty accepting such an important role for the Parliament in the drafting of the SCO list, those dynamics might change. Two general explanations support this point: (1) the future and increasing integration of asylum policies at the EU level and (2) the increasing influence the European Parliament will gain overall in other areas due to expanded powers granted by the Lisbon Treaty.

The neofunctionalist concept of spillover proves very useful in tackling the first point. As interdependence between Member States will continue to increase throughout various fields, the functional spillover will also intensify and the need for increasingly harmonized asylum policies

5. These were also the only three countries that the majority of Member States judged to be safe. 
will become more prominent. For example, although Member States are not publicly contemplating the creation of a common SCO list at this point, the Council and the Commission have called for the consolidation of the common criteria used for national designations of countries as safe to achieve more consistent applications of the principle across the EU. This means that the push for harmonization of this principle is still active. In this respect, it is important to point out that in April 2007 Member States adopted the "Common EU guidelines for processing Country of Origin Information,” while in November 2010 the European Commission put forward a set of common guidelines for Member States to use in setting up joint fact-finding missions to assess conditions in a country of origin (Office of the Commissioner General for Refugees and Stateless Persons 2010). Furthermore, the newly created European Asylum Office could lead to an even deeper harmonization if there was a true will to allow this body to play an important role coordinating the activities of Member States in this field. Hence, it is clear that deeper harmonization of the understandings underpinning concepts like "country of origin" could eventually lead to a spillover in policy areas related to them, including the "safe country of origin" asylum tool. The debate over the common SCO list could be revived since future harmonization in the asylum field will eventually make the utilization of the list at the national level unsustainable. Lastly, some may raise the issue of sovereignty, anticipating Member States' reluctance to give up power in sensitive areas such as asylum. However, as Lavenex points out, while the sovereignty argument holds true in certain aspects of the asylum field, "the European asylum frame has affected traditional refugee regimes by [...] shifting the emphasis of international co-operation in refugee policy away from the internal aspect of refugee reception towards the external and-from the point of view of sovereignty-less sensitive aspect of flight prevention in the region of origin" (2001, 855).

Regarding the role of the European Parliament, it is important to note that liberal intergovernmentalists do not really envision supranational bodies gaining any considerable influence. Thus, it is difficult for liberal intergovernmentalists to envision the Parliament playing the role of co-decider in the SCO list. Moreover, the theory would, in general, have problems explaining the increased responsibility of the Parliament under the Lisbon Treaty. However, neofunctionalists can fill this gap. This theory presupposes that supranational bodies like the European Commission can play an important role in the European integration process, cultivating the logic of interdependence (Niemann and Schmitter 2009, 50). While the theory traditionally only mentions the Commission, this paper applies the neofunctionalist argument to the Parliament as well, especially since its increased powers are a fairly recent phenomenon.

According to the neofunctionalist argument, the actors' interests are likely to change during the integration process, as they gain experience in cooperative decision making and perceive the salience of supranational solutions to problems. While the Court brought down its decision in 2008 based on the two Treaties forming the EU at that time, ${ }^{6}$ the entry into force of the Lisbon Treaty in 2009 handed the European Parliament even more co-legislative powers. This is likely to change the working dynamic of the Member States (through the Council) and the Parliament, where cooperation and compromise will become increasingly important. It might be fair to assume then that in time, as the Parliament starts exercising its new powers in areas such as trade policy, for

6. The Treaty of the European Union (Maastricht Treaty) and the Treaty on the Functioning of the European Union (Rome Treaty). 
example-and as new precedents for cooperation are set-Member States might also envision cooperating more closely with it for the creation of a common SCO list. Hence, neofunctionalists' spillover concept and the fluidity of actors' interests indicate that reviving the debate over the common SCO list might be just a matter of time.

The question that follows is what impact could the European Parliament have in the creation of such a list? Neofunctionalists see supranational institutions such as the Commission as actors who play the role of mediator, facilitating a bargaining process that upgrades common interests. It is true the Commission and the Parliament have different roles in the EU structure, but it is clear that the increased powers of the Parliament call for a revisiting of the neofunctionalist integration theory to account for the impact of these changes.

During the drafting of the 2005 Asylum Directive that laid down the SCO provisions, the Parliament's suggested amendments were largely aimed at strengthening the guarantees for the applicants. The same is happening during the current recast of this directive (European Commission 2011). Similarly, it is important to remember that before the initial adoption of the directive, the Parliament had been quite critical of the SCO list proposal. In a non-binding move at the time, it had voted down several sections dealing with the notion of creating a list of "safe countries." Nevertheless, it is important to point out that the Parliament was not against the SCO principle per se. A look at some of the proposed amendments, both in 2005 and during the current recast, indicate the shaping of a debate over whether a common SCO list would still require maintaining national lists or whether a sole supranational one would fulfill a better purpose (European Union Delegation at the United Nations 2005).

While it is difficult to suggest whether the Parliament's position on these matters has changed today, one might at least make a general assumption that having the Parliament as a co-decider for a common SCO list could indeed upgrade the actors' interests to perhaps less restrictive policies, and-implicitly-result in more rights for asylum seekers. Conversely, one might question whether the Parliament's past pragmatic stance on asylum issues was a reflection of its less powerful role within the EU framework, a way to differentiate itself in the decision making body. Hence, it would be interesting to trace whether and how this position might change in the postLisbon environment. Overall though, it is important to recognize that these questions require further research as they remain highly speculative at this point.

\section{Conclusion}

This paper focused on a specific asylum policy tool, the "safe country of origin" policy, and tried to explain its evolution at the EU level through the lenses of two integration theories. The varied procedural use of the principle at the national level, or lack thereof in some countries, explains Member States' difficulty in reaching agreement over what countries should feature on the common SCO list. The above sections theorized about the bargaining process behind the creation of such a list and tested liberal intergovernmentalism's and neofunctionalism's relevancy in explaining both past developments in this areas, as well as their capacity to point to a way forward.

This paper argued that the current impasse in the creation of a common SCO list could be temporary. There are several variables that could put an end to the current stalemate. First, it is important to see the final version of the 2005 Directive, which is now under recast. This will provide a good indication regarding the direction supranational asylum policies are moving towards. Second, while the updated version of the Directive might not call for the creation of a supranational SCO list, it will be interesting to observe how this policy will develop at the Member State level and whether there will be room for procedural convergence. Third, the 
integration of other asylum policies such as the common fact-finding missions could also impact the re-opening of the SCO debate. Fourth, it is also important to track the changing dynamics between the Member States and a much stronger European Parliament. Depending on their development, these factors could influence the reopening of the SCO debate.

Lastly, some of the arguments of this paper remain speculative at this point, but deeper research-through interviews with nationals and EU officials-could shed more light on the internal perspectives of Member States and EU institutions.

\section{ACKNOWLEDGEMENTS}

The author would like to thank Achim Hurrelmann for his suggestions and guidance; Martin Geiger, whose class first inspired this paper; the three discussants who provided their feedback during the conferences this paper was presented at; and Aysegül Ergul for her comments and encouragement.

\section{REFERENCES}

Costello, Cathryn. 2005. "The Asylum Procedures Directive and the Proliferation of Safe Country Practices: Deterrence, Deflection and the Dismantling of International Protection?” European Journal of Migration and Law 7: 35-69.

Council of the European Union. 2004a. "Amended Proposal for a Council Directive on Minimum Standards on Procedures in Member States for Granting and Withdrawing Refugee Status." Interinstitutional File 2000/0238. Document number 8771/04, April 30.

Council of the European Union. 2004b. Note from the Presidency. Interinstitutional File 2000/0238. Document number 14383/04, November 9.

Council Directive 2005/85/EC. "Minimum Standards on Procedures in Member States for Granting and Withdrawing Refugee Status.” December 1.

EurActiv.com. "EU Asylum Policy: Ministers Criticized Over List of Safe Countries." November 5, 2003. http://www.euractiv.com/security/eu-asylum-policy-ministers-criticised-list-safecountries/article-112329.

BBC News. "EU Parliament Backs Asylum Bill.” September 27, 2005. http://news.bbc.co.uk/2/hi/europe/4285306.stm.

European Commission. 2009. "Proposal for a Directive of the European Parliament and of the Council on Minimum Standards on Procedures in Member States for Granting and Withdrawing International Protection (Recast).” Document number 2009/0165, October 21.

— 2010. "Report from the Commission to the European Parliament and the Council on the Application of Directive 2005/85/EC," September 8.

- 2011. "Amended Proposal for a Directive of the European Parliament and of the Council on Minimum Standards on Procedures in Member States for Granting and Withdrawing International Protection (Recast),” Document number COM(2011) 319, June 1.

European Court of Justice. 2008. Judgment in Case C-133/06. Parliament v Council, May 6.

European Union. 1992. "Conclusions on Countries in Which There is Generally No Serious Risk of Persecution ('London Resolutions').” November 30. http://www.unhcr.org/refworld/publisher,EU,,,3f86c6ee4,0.html. 
European Union Delegation at the United Nations. 2005. "Summary: EU Parliament-Minimum EU Standards for Granting Refugee Status,” September 25. http://www.europa-euun.org/articles/en/article_5066_en.htm.

Hailbronner, Kay. 1993. “The Concept of 'Safe Country’ and Expeditious Asylum Procedures: A West European Perspective.” International Journal of Refugee Law 5, 1: 31-65.

Kraft-Kasack, Christiane and Mariya Shisheva. 2008. "The Communitarization of Asylum and Immigration Policy at Amsterdam: A Liberal Intergovernmentalist Account.” Working Paper, Hertie School of Governance, no. 31, April.

Kubosova, Lucia. "Frattini Set to Come Up With Longer List of 'Safe' Countries.” Euobserver.com, June 2, 2006. http://euobserver.com/justice/21764.

Kubosova, Lucia, and Teresa Küchler. 2006. “Commissioners Divided over EU List of 'Safe' Countries.” Euobserver.com, May 24. http://euobserver.com/justice/21687.

Lavenex, Sandra. 2001. “The Europeanization of Refugee Policies: Normative Challenges and Institutional Legacies.” Journal of Common Market Studies 39 (5): 851-74.

Leimsidor, Bruce. 2009. “Ten Years after Tampere (1999-2009): Coordinating and Harmonizing European Asylum Policy: Is it Possible, or Desirable?” Paper presented at a conference organized by McGill University’s Faculty of Law, Montreal, Canada, March 13.

Lindstrom, Channe. 2005. "European Union Policy on Asylum and Immigration. Addressing the Root Causes of Forced Migration: A Justice and Home Affairs Policy of Freedom, Security and Justice?” Social Policy and Administration 39, 6: 587-605.

Moravcsik, Andrew, and Frank Schimmelfennig. 2009. “Liberal Intergovernmentalism.” In European Integration Theory, edited by Antje Wiener and Thomas Diez, 67-87. Oxford: Oxford University Press.

Niemann, Arne, and Philippe C. Schmitter. 2009. "Neofunctionalism.” In European Integration Theory, edited by Antje Wiener and Thomas Diez, 45-66. Oxford: Oxford University Press. Oakley, Sharon. 2007. “Accelerated Procedures for Asylum in the European Union: Fairness Versus Efficiency.” Working Paper no. 43, Sussex Centre for Migration Research, April. Office of the Commissioner General for Refugees and Stateless Persons. 2010. "EU common Guidelines on (Joint) Fact Finding Missions: A Practical Tool to Assist Member States in Organizing (Joint) Fact Finding Missions,” November.

Pasquetti, Stefania, Acting Head of Asylum Unit at the Directorate General for Home Affairs. Letter Response. December 9, 2011.

Statewatch. "EU Divided over List of 'Safe Countries of Origin' -The List Should be Scrapped," September 27, 2004. http://www.statewatch.org/analyses/no-38-safe-countries.pdf.

- "Appendix: Is the Country Suitable for Inclusion on the Minimum Common List?" September 27, 2004. http://www.statewatch.org/news/2004/sep/safe-countries-Appendix.pdf. Travis, Alan. "EU Asylum List Prompts Human Rights Fears.” The Guardian, September 27, 2004. http://www.guardian.co.uk/politics/2004/sep/27/eu.immigration.

United Nations High Commissioner for Refugees (UNHCR). 1991. "Background Note on the Safe Country Concept and Refugee Status,” July 26. http://www.unhcr.org/refworld/docid/3ae68ccec.html.

— 2010. "Improving Asylum Procedures: Comparative Analysis and Recommendations for Law and Practice,” March. http://www.unhcr.org/4ba9d99d9.html. 
Correct citation: Gurzu, Anca. 2012. "Safe Country of Origin List at the EU Level: The Bargaining Process and the Implications.” Review of European and Russian Affairs 7 (1): 1-14.

Published by the Centre for European Studies at Carleton University, Ottawa, Canada. Available online at: www.carleton.ca/rera/

RERA is an electronic academic peer-reviewed journal that publishes graduate, post-graduate, and young scholarly works. Topics relate to the European Union, its Member States, the former Soviet Union, and Central and Eastern Europe. The journal is a joint project supported by the Canada-Europe Transatlantic Dialogue-a cross-Canada research network supported by the Social Sciences and Humanities Research Council of Canada (SSHRC) — along with the Institute of European, Russian and Eurasian Studies (Carleton University) and its associated research unit, the Centre for European Studies.

RERA aims to provide an accessible forum for research, to promote high standards of research and scholarship, and to foster communication among young scholars.

\section{Contact:}

Carleton University

The Centre for European Studies

1103 Dunton Tower

1125 Colonel By Drive

Ottawa, ON

K1S 5B6

Canada

Tel: +01 613 520-2600 ext. 1179; E-mail: rera-journal@carleton.ca

\section{Creative Commons License}

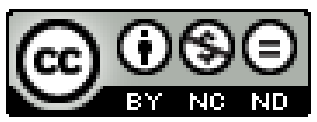

http://creativecommons.org/licenses/by-nc-nd/3.0/

This Working Paper is licensed under a Creative Commons Attribution-Non-CommercialNo Derivs 3.0 Unported License (CC BY-NC-ND 3.0).

Articles appearing in this publication may be freely quoted and reproduced provided the source is acknowledged. No use of this publication may be made for resale or other commercial purposes.

ISSN: 1718-4835

(C) 2012 The Author(s) 